\title{
GIS-Based Assessment of Groundwater Quality for Drinking in Perambalur District of Tamil Nadu
}

\author{
S. Vinothkanna, R. Rajee and K. Senthilraja ${ }^{1}$ \\ Department of Geography, Madurai Kamaraj University, Madurai-625 021, India \\ ${ }^{1}$ Agro Climate Research Centre, Tamil Nadu Agricultural University, Coimbatore-641 003, India \\ E-mail: vinothkanna.gis@gmail.com
}

\begin{abstract}
Water quality parameters such as TDS, $\mathrm{Ca}^{2+}, \mathrm{Mg}^{2+}, \mathrm{Na}^{+}, \mathrm{K}, \mathrm{Cl}, \mathrm{So}_{4}{ }^{2}, \mathrm{~F}, \mathrm{pH}$ and $\mathrm{TH}$ were used to determine the groundwater quality in the Perambalur district of Tamil Nadu. The BIS scale is used to determine the water quality index based on standard weight. The chemical ion indicates that an alkali exceeds alkaline earth and weak acids exceed strong acids in both monsoon periods. The highest numbers of wells where the chemical constituents were above the permissible limit with $\mathrm{Mg}^{2+}$, TDS and total hardness and the lowest was in Ca ${ }^{2+}$. In 2018, poor water quality covered $1345 \mathrm{sq} \mathrm{km}$ in pre-monsoon and $1203 \mathrm{sq} \mathrm{km}$ in the post-monsoon season. Therefore, it is imperative to improve water quality using proper water purification and pollution control in areas where poor water quality is noted.
\end{abstract}

Keywords: $\mathrm{Ca}^{2+}$, BIS standards, Groundwater, Drinking water quality, Monsoon

The groundwater chemistry is unique and its quality is determined by the geological formation, climatic condition and anthropogenic activities. The groundwater is a valuable resource for drinking, agriculture and industrial activities around the world (Adimalla Narsimha et al 2018). Groundwater accounts for nearly 65,20 and $15 \%$ of drinking, irrigation and industrial activities respectively based on recent research (Salehi et al 2018). In India, 90\% of the rural community be influenced by groundwater for drinking and domestic purposes (Arya et al 2019). Generally, the groundwater is less vulnerable to contamination but once the groundwater gets polluted it is difficult to retain its original content (Vinothkanna et al 2020). However, the geochemistry of groundwater determines its utilization whether for domestic or agriculture (Vinothkanna 2019). Many studies on groundwater using standard techniques and plots were carried out by various researchers (Divahar et al 2020 for Kalingarayan canal of Erode district; Vinothkanna et al 2020 for Dharmapuri district of Tamil Nadu; Ramprasad et al 2021 for river Cauvery and Vaigai upstream and downstream locations of Tamil Nadu). Water quality index (WQI) is a widely used technique to assess quality (Gorgij et al 2017). The WQI is a frequently used method because of considering important chemical parameters to determine the water quality. The use of a Geographic Information System (GIS) in water resources provides commendable information to the research. Many researchers used GIS techniques in water quality studies (Jasmin and Mallikarjuna 2014 for Araniar River Basin; Vinothkanna et al 2016 for Namakkal district). The main purpose of this study is to assess the quality of groundwater for domestic purposes in the Perambalur district of Tamil Nadu. Understanding groundwater chemistry helps to use this resource optimistic and make it sustain.

\section{MATERIAL AND METHODS}

Study area: The spatial extent of Perambalur district is 1757 sq. $\mathrm{km}$ and located in the interior part of Tamil Nadu with a geographical extent of $10^{\circ} 54^{\prime \prime}$ to $11^{\circ} 30^{\prime \prime} \mathrm{N}$ and $78^{\circ} 40^{\prime \prime}$ to $79^{\circ} 30 " \mathrm{E}$ (Fig. 1). River Vellar and Pachmalai hill in the north and Kollidam River in the south are the prominent physical features. Sugarcane is one of the main crops cultivated in this district. The major factors which define the geomorphology of the study area are denudational, structural and fluvial processes. Black, alluvial and red loamy soils are the major soil categories distributed in the district. Hydro geologically the aquifer system is constituted by Basalt crystalline rocks comprising Charnockites, Granites and Gneisses of Archean age and sedimentary formation from Cretaceous to recent.

Methods: The groundwater data for 2018 were collected from the state ground and surface water resources data centre, Chennai is the primary source for this analysis. The 19 common groundwater wells from different monsoon seasons (pre and post) were identified using Microsoft Excel and attributed to the ArcGIS platform to show spatially. Based on the Bureau of Indian Standard (BIS) a total of ten water quality parameters viz., TDS, $\mathrm{Ca}^{2+}, \mathrm{Mg}^{2+}, \mathrm{Na}^{+}, \mathrm{K}^{+}, \mathrm{Cl}, \mathrm{SO}_{4}^{2}, \mathrm{~F}$, $\mathrm{pH}$ and Total hardness were considered to identify the 
groundwater quality for domestic purposes (Narsimha Adimalla 2019). The weight was assigned from 1 to 5 (Table 1.) based on the importance of drinking purpose and by using the arithmetic index method relative weight was calculated (Chaurasia et al 2018).

$$
W \mathrm{WI}=\Sigma \text { qiwi }
$$

Where qi (ground water quality ranking $)=100 \times(V a-V i) /$ (Vs-Vi),

When $\mathrm{Va}=$ authentic value found in the groundwater sample

$\mathrm{Vi}=$ ideal value $\left(\mathrm{pH}\right.$ and $\mathrm{DO}$ have 7.0 and $14.6 \mathrm{mgL}^{-1}$ respectively and 0 for all other parameters).

Vs = standard value.

$\mathrm{Wi}$ (unit weight) $=\mathrm{KSn}^{-1}$

Where K constent $=\frac{1}{\frac{1}{V_{s} 1}+\frac{1}{V_{s} 2} \frac{1}{V_{s} 3} \frac{1}{V_{s} 4} \ldots \ldots . .+\frac{1}{V s n}}$

$S n=$ ' $n$ ' number of standard values.

GIS analysis: The district boundary was digitized using Topographic sheets collected from the Survey of India with a

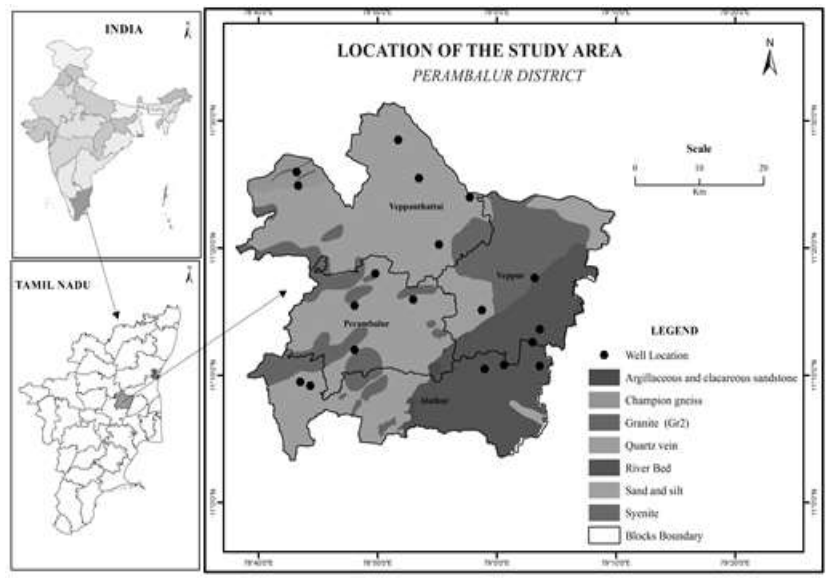

Fig. 1. Location of the study area - Perambalur District

Table 1. Standard limits and their relative weight

\begin{tabular}{lcccc}
\hline Parameters & $\begin{array}{c}\text { BIS standards (2012) } \\
\text { acceptable limit }\end{array}$ & $\begin{array}{c}\text { WHO limit } \\
(2011)\end{array}$ & $\begin{array}{c}\text { Weight } \\
\text { (Wi) }\end{array}$ & $\begin{array}{c}\text { Relative } \\
\text { weight }\end{array}$ \\
\hline $\mathrm{Ca}^{2+}$ & 75 & 100 & 2 & 0.068 \\
$\mathrm{Cl}$ & 250 & 250 & 3 & 0.103 \\
$\mathrm{~F}$ & 1 & 1.5 & 5 & 0.172 \\
$\mathrm{~K}^{+}$ & 12 & 12 & 1 & 0.034 \\
$\mathrm{Mg}^{2+}$ & 30 & 50 & 2 & 0.068 \\
$\mathrm{Na}^{+}$ & 50 & 200 & 3 & 0.103 \\
$\mathrm{pH}^{2+}$ & $6.5-8.5$ & $6.5-8.5$ & 3 & 0.103 \\
$\mathrm{Sulfate}$ & 200 & 400 & 3 & 0.103 \\
$\mathrm{TDS}$ & 500 & 1000 & 5 & 0.172 \\
$\mathrm{TH}$ & 200 & 500 & 2 & 0.068 \\
\hline
\end{tabular}

scale of 1:50,000 using UTM coordinates. The spatial map for water quality was prepared using the interpolation technique in ArcGIS mainly the Inverse Distance Weight (IDW) method because it is easy to perform. This method gives weightage to the observed point and predicts a value for an unknown location (Elumalai et al 2017).

\section{RESULTS AND DISCUSSION}

Groundwater chemistry controlling mechanism: On the left side of the plot are cations that constitute $\mathrm{Mg}^{2+}, \mathrm{Ca}^{2+}, \mathrm{Na}^{+}$ and $\mathrm{K}^{+}$and the right-side triangle is anions comprise of $\mathrm{Cl}$, $\mathrm{SO}_{4}^{2}, \mathrm{CO}^{3}$ and $\mathrm{HCO}^{3}$ (Fig. 2). The presence of $\mathrm{Na}^{+}+\mathrm{K}^{+}$ions in the groundwater is due to silicate weathering (Lakshmanan et al 2003). Similarly, the anions are dominated by bicarbonates and were in the order of $\mathrm{HCO}^{3}>\mathrm{Cl}>\mathrm{SO}_{4}^{2}$. Generally, the diamond field is divided into 4 geochemical categories such as a) $\mathrm{Ca}^{2+}-\mathrm{Mg}^{2+}-\mathrm{HCO}^{3}$, b) $\mathrm{Ca}^{2+}-\mathrm{Mg}^{2+}-\mathrm{Cl}_{-} \mathrm{SO}_{4}^{2}$, c) $\mathrm{Na}+-\mathrm{K}+-\mathrm{Cl}-\mathrm{SO}_{4}^{2}$ and d) $\mathrm{Na}^{+}-\mathrm{K}^{+}-\mathrm{HCO}^{3}$. The chemical ions are presented in the order of $\mathrm{Na}^{+}-\mathrm{K}^{+}-\mathrm{Cl}-\mathrm{SO}_{4}^{2}>\mathrm{Na}^{+}-\mathrm{K}^{+}-$ $\mathrm{HCO}^{3}>\mathrm{Ca}^{2+}-\mathrm{Mg}^{2+}-\mathrm{HCO}^{3}>\mathrm{Ca}^{2+}-\mathrm{Mg}^{2+}-\mathrm{Cl}-\mathrm{SO}_{4}^{2}$ indicates alkalis exceeds alkaline earth and weak acids exceed strong acids in both monsoon period.

\section{Characteristics of Chemical Parameters}

Calcium: The mean value of $\mathrm{Ca}^{2+}$ ranged between 10 to 80 $\mathrm{mgL}^{-1}$ and 8 to $60 \mathrm{mg} \mathrm{L}^{-1}$ during pre-monsoon and postmonsoon season respectively (Table 2 \& Fig. 3a). During premonsoon seasons, 18 wells (95\%) were in the desirable range and only 1 well located in Esanai village exceeds the desirable limit which is located in the central part depicted on the spatial map. During the post-monsoon season, almost all the wells are under desirable limits during the study.

Chloride: The chloride level in the pre-monsoon season varied from 35 to $596 \mathrm{mg} \mathrm{L}^{-1}$ and during the post-monsoon season it is 28 to $709 \mathrm{mg} \mathrm{L}^{-1}$ (Fig. 3b). The chloride level in pre-monsoon and post-monsoon season show that 79 and 74 percent of wells are under the desirable limit.

Fluoride: The fluoride in pre monsoons season ( 0.05 to 1.4 $\mathrm{mg} \mathrm{L}^{-1}$ ) are having an average of $0.48 \mathrm{mg} \mathrm{L}^{-1}$. About 84 percent of pre-monsoon sample wells are under the desirable limit as prescribed by BIS standards (2012). Pasumbalur village of Veppanthattai taluk, Sirumathur and Chittali village of Kunnam taluk fluoride were above the desirable limit. But in the post-monsoon, fluoride values are range from 0.13 to $1.22 \mathrm{mg} \mathrm{L}^{-1}$ having a mean value of 0.56 $\mathrm{mg} \mathrm{L}^{-1}$ (Fig. $3 \mathrm{c}$ ). The desirable range was in 16 and 3 wells (Mettupalayam village of Veppanthattai taluk, Sirumattur and Kilumattur village of Kunnam taluk) exceeds desirable value during the study period.

Potassium: The concentration of potassium was 0.1 to 196 $\mathrm{mg} \mathrm{L}^{-1}$ for pre-monsoon and 18 to $98 \mathrm{mg} \mathrm{L}^{-1}$ for post-monsoon 
was noted during the study period (Fig. 3d). The mean values of potassium are observed as $43.2 \mathrm{mg} \mathrm{L}^{-1}$ for pre-monsoon and $50.3 \mathrm{mg} \mathrm{L}^{-1}$ for the post-monsoon season. Among the total samples, 58 percent in pre-monsoon and only 16 percent in post-monsoon are under the desirable limit. The samples found beyond the desirable limit are 42 percent (pre-

Table 2. Groundwater chemical parameters - Perambalur district

\begin{tabular}{|c|c|c|c|c|c|c|c|c|c|c|c|c|}
\hline \multirow[t]{2}{*}{ Parameter } & \multirow{2}{*}{$\begin{array}{c}\text { Desirable } \\
\text { limit } \\
\left(\mathrm{mgL}^{-1}\right)\end{array}$} & \multicolumn{3}{|c|}{ Pre-monsoon } & \multicolumn{3}{|c|}{ Post-monsoon } & \multirow[t]{2}{*}{ Classification } & \multicolumn{2}{|c|}{ Pre-monsoon } & \multicolumn{2}{|c|}{ Post-monsoon } \\
\hline & & Mean & Maximum & Minimum & Mean & Maximum & Minmum & & $\begin{array}{l}\text { Total } \\
\text { well }\end{array}$ & $\%$ & $\begin{array}{l}\text { Total } \\
\text { well }\end{array}$ & $\%$ \\
\hline \multirow[t]{2}{*}{$\mathrm{Ca}$} & 75 & 42.7 & 80.0 & 10.0 & 34.21 & 60.0 & 8.0 & WL & 18 & 94.74 & 19 & 100 \\
\hline & & & & & & & & $\mathrm{AL}$ & 1 & 5.26 & 0 & 0 \\
\hline \multirow[t]{2}{*}{$\mathrm{Cl}$} & 250 & 188.9 & 596.0 & 35.0 & 214.68 & 709.0 & 28.0 & WL & 15 & 78.95 & 14 & 73.68 \\
\hline & & & & & & & & $\mathrm{AL}$ & 4 & 21.05 & 5 & 26.32 \\
\hline \multirow[t]{2}{*}{$F$} & 1.0 & 0.4 & 1.4 & 0.05 & 0.56 & 1.2 & 0.1 & WL & 16 & 84.21 & 16 & 84.21 \\
\hline & & & & & & & & $\mathrm{AL}$ & 3 & 15.79 & 3 & 15.79 \\
\hline \multirow[t]{2}{*}{ K } & 20 & 43.2 & 196.0 & 0.1 & 50.37 & 98.0 & 18.0 & WL & 11 & 57.89 & 3 & 15.79 \\
\hline & & & & & & & & $\mathrm{AL}$ & 8 & 42.11 & 16 & 84.21 \\
\hline \multirow[t]{2}{*}{$\mathrm{Mg}$} & 30 & 72.6 & 167.6 & 24.3 & 58.38 & 98.42 & 21.8 & WL & 3 & 15.79 & 3 & 15.79 \\
\hline & & & & & & & & $\mathrm{AL}$ & 16 & 84.21 & 16 & 84.21 \\
\hline \multirow[t]{2}{*}{$\mathrm{Na}$} & 200 & 183.5 & 621.0 & 12.0 & 166.32 & 495.0 & 24.0 & WL & 13 & 68.42 & 13 & 68.42 \\
\hline & & & & & & & & $\mathrm{AL}$ & 6 & 31.57 & 6 & 31.58 \\
\hline \multirow[t]{2}{*}{$\mathrm{pH}$} & $6.5-8.5$ & 8.3 & 8.6 & 8.1 & 8.11 & 8.3 & 7.7 & WL & 17 & 89.47 & 19 & 100 \\
\hline & & & & & & & & $\mathrm{AL}$ & 2 & 10.53 & 0 & 0 \\
\hline \multirow[t]{2}{*}{ So4 } & 200) & 254.5 & 864.0 & 24.0 & 156.00 & 600.0 & 29.0 & WL & 9 & 47.37 & 15 & 78.95 \\
\hline & & & & & & & & $\mathrm{AL}$ & 10 & 52.63 & 4 & 21.05 \\
\hline \multirow[t]{2}{*}{ TDS } & 500 & 1048.3 & 2697.0 & 226.0 & 920.74 & 1925.0 & 276.0 & WL & 3 & 15.79 & 5 & 26.32 \\
\hline & & & & & & & & $\mathrm{AL}$ & 16 & 84.21 & 14 & 73.68 \\
\hline \multirow[t]{2}{*}{$\mathrm{TH}$} & 200 & 405.7 & 840.0 & 150.0 & 325.79 & 510.0 & 125.0 & WL & 4 & 21.05 & 4 & 21.05 \\
\hline & & & & & & & & $\mathrm{AL}$ & 15 & 78.95 & 15 & 78.95 \\
\hline
\end{tabular}

(WL - Within Limit, AL - Above Limit)
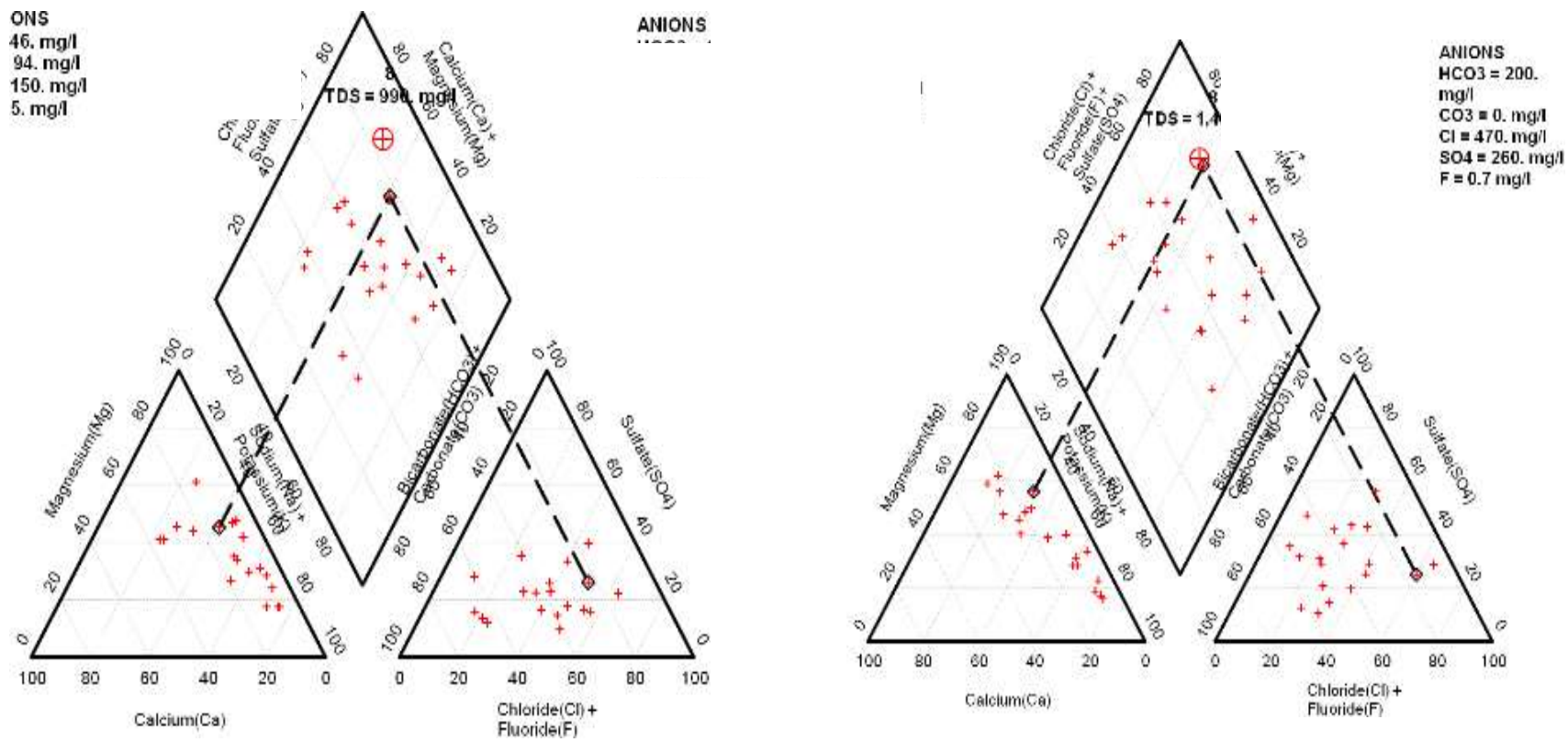

Fig. 2. Pre-Monsoon and post-monsoon season Piper diagram 

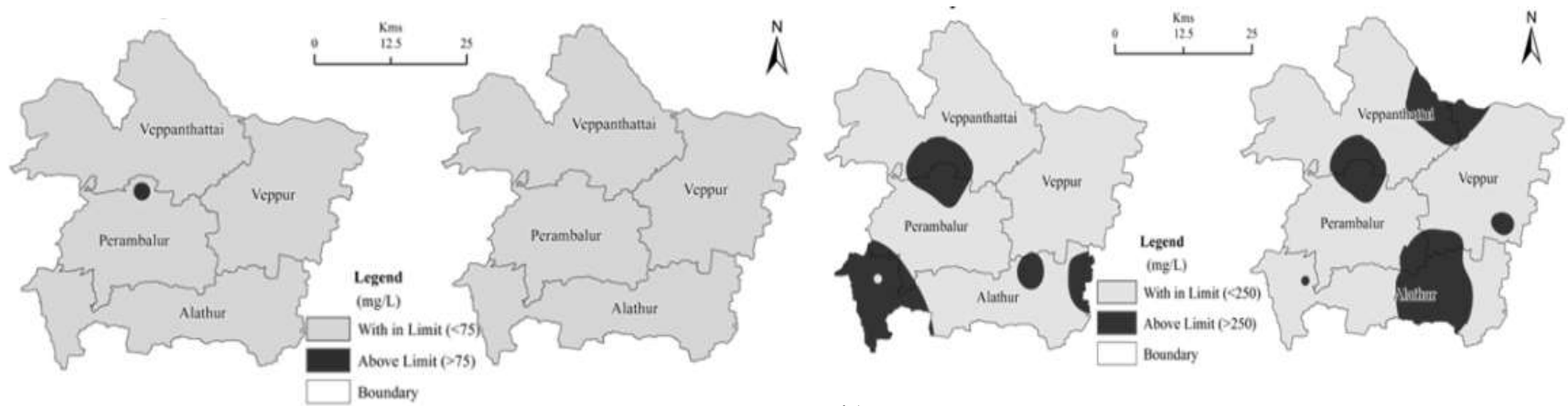

b)

a)
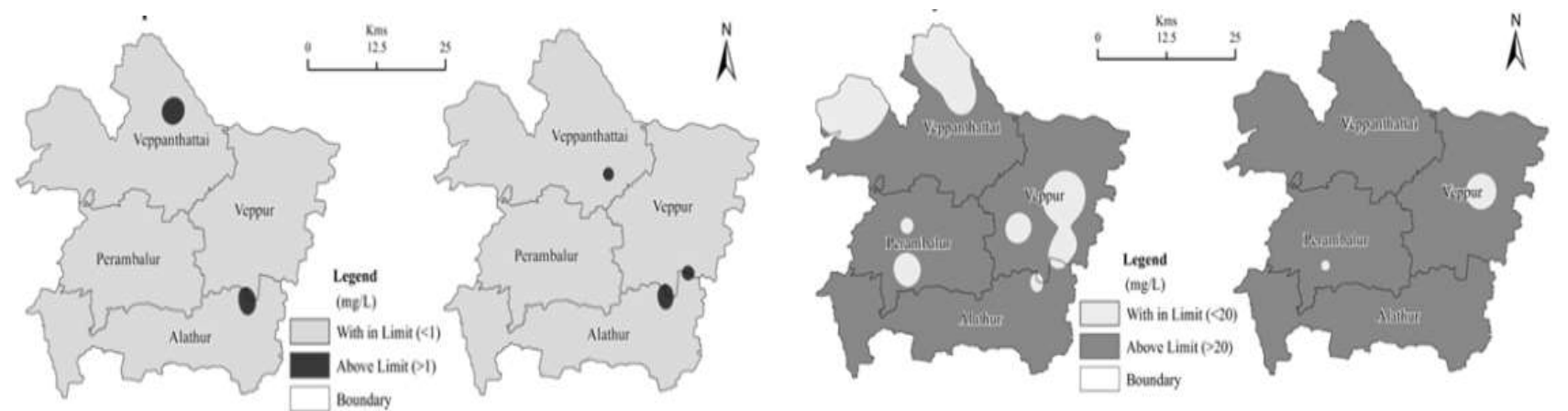

c)

d)
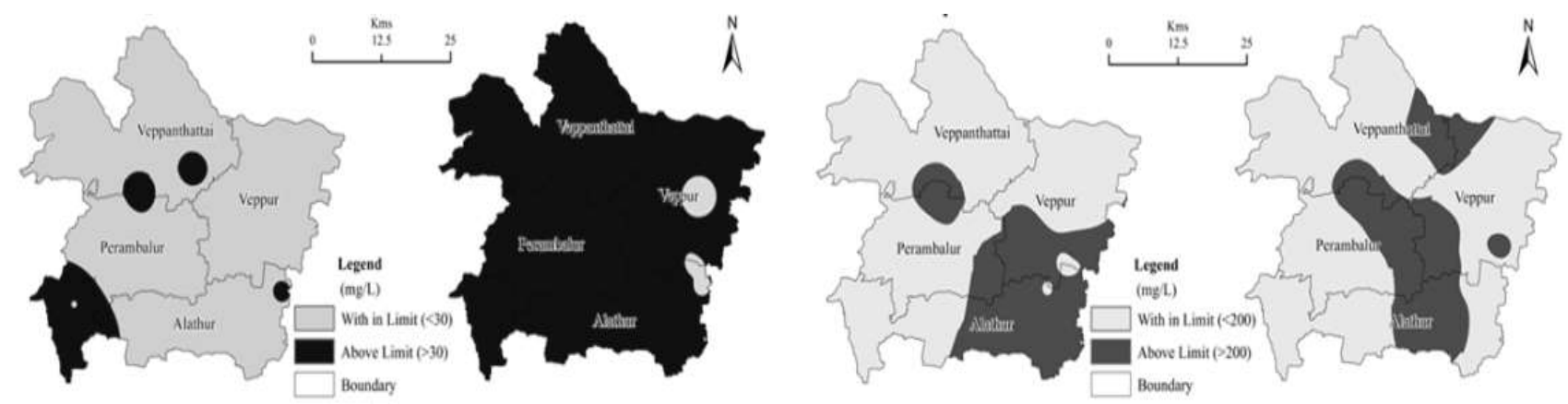

e)

f)
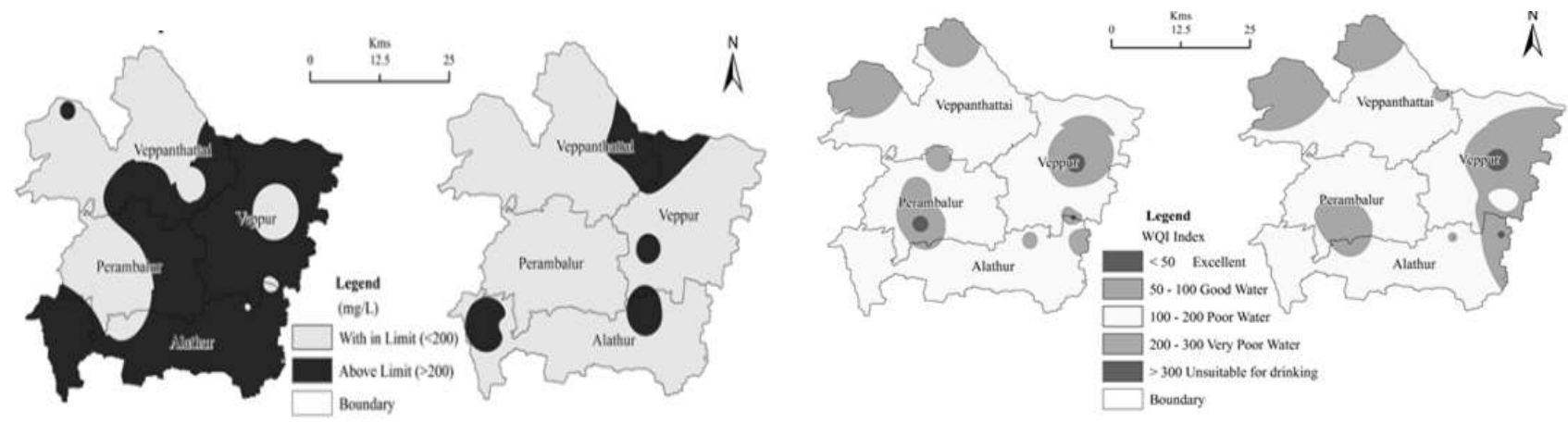

h)

g)

Fig. 2. Spatial distribution map of water quality parameters a) Calcium, b) Chloride, c) Fluoride, d) Potassium e) Magnesium f) Sodium g) Sulfate h) WQI 
monsoon) and 84 percent (post-monsoon). The excess amount of potassium is present in the groundwater is due to the high use of potassium fertilizer in the agriculture field leads to percolates into the groundwater (Augustine and Anitha Pius 2018).

Magnesium: The mean values of magnesium for premonsoon was $73 \mathrm{mg} \mathrm{L}^{-1}$ and in post-monsoon $58 \mathrm{mg} \mathrm{L}^{-1}$ (Fig. $3 e$ ). The magnesium values are range from 24.3 to 167.67 $\mathrm{mg} \mathrm{L}^{-1}$ for pre-monsoon and 21.8 to $98.42 \mathrm{mg} \mathrm{L}^{-1}$ for the postmonsoon season. Magnesium value indicates that 84 percent of samples are above the desirable limit in both monsoon seasons during the study period. The spatial map shows that except for small patch in the northern and eastern parts all other areas are beyond the limit prescribed.

Sodium: Sodium value during the pre-monsoon season varied from 12 to $621 \mathrm{mg} \mathrm{L}^{-1}$ with a mean of $183.58 \mathrm{mg} \mathrm{L}^{-1}$ and in post-monsoon season 24 to $495 \mathrm{mg} \mathrm{L}^{-1}$ with mean value of $166.32 \mathrm{mg} \mathrm{L}^{-1}$ (Fig. 3f). The 32 percent of groundwater samples are above the desirable limit during the study period. Excess intake of sodium content in water to humans causes hypertension, kidney and nervous disorders (Subba Rao et al 2012).

pH: During 2018, the $\mathrm{pH}$ ranged from 8.1 to 8.6 and 7.7 to 8.3 in pre and post-monsoon season respectively. Among the samples, 89 percent of samples observed in pre and 100 percent in post-monsoon season are under the desirable limit for the period of study. The permissible level of $\mathrm{pH}$ in groundwater is 6.5-8.5 (WHO 2011). Only two samples in pre-monsoon are exceeded the desirable limit found in the villages of Periyar in Vepanthattai taluk and Kilmattur village of Kunnam taluk.

Sulfate: The sulfate in the pre-monsoon period varied from 24 to $864 \mathrm{mg} \mathrm{L}^{-1}$ with a mean of $254.58 \mathrm{mg} \mathrm{L}^{-1}$ and for the postmonsoon season, the values are 29 to $600 \mathrm{mgL}^{-1}$ with a mean value of $156 \mathrm{mg} \mathrm{L}^{-1}$. In the pre-monsoon period, 9 wells are under the desirable range, which is shown in the northwestern part and 10 wells have exceeded the desirable range, which is noted in the southeastern and northeastern part of the area (Fig. $3 g$ ). During the post-monsoon season, $15(78.95 \%)$ wells were in the south-western and southeastern part of the area indicate the desirable range, while the 4 wells such as the villages of ChittaliNakkaselam, Kottarai of Kunnam taluk and Peraiyur village of Veppanthattai taluk were above the desirable range.

Total dissolved solids: The TDS values present in the groundwater ranged from 226 to $2697 \mathrm{mg} \mathrm{L}^{-1}$ (pre monsoon) and 276 to $1925 \mathrm{mg} \mathrm{L}^{-1}$ (post-monsoon season). Only 3 (16\%) wells are in the desirable range found in Perambalur and Kunnam villages, the remaining 16 (84\%) wells were above the desirable range and spatially distributed almost the entire
Table 3. Domestic water quality index-Perambalur District2018

\begin{tabular}{llcc}
\hline $\begin{array}{l}\text { WQI } \\
\text { classification }\end{array}$ & Categories & $\begin{array}{c}\text { Pre-monsoon } \\
(\text { sq.km) }\end{array}$ & $\begin{array}{c}\text { Post-monsoon } \\
(\text { sq.km) }\end{array}$ \\
\hline$<50$ & Excellent & 17.36 & 14.711 \\
$50-100$ & Good water & 359.10 & 532.69 \\
$100-200$ & Poor water & 1345.00 & 1203.42 \\
$200-300$ & Very poor water & 36.54 & 7.4 \\
$>300$ & Unfit for drinking & - & - \\
\hline
\end{tabular}

study area. But during post-monsoon season, 5 (26\%) wells are under the desirable range and 14 (74\%) wells fall above the desirable limit during the study period. Selvam et al (2013) studied that the excess presence of TDS is due to salts having a high connection with the subsurface lithology and much time in contact with the aquifer body.

Total hardness: The $\mathrm{TH}$ ranged from 150 to $840 \mathrm{mg} \mathrm{L}^{-1}$ with a mean of $405.7 \mathrm{mg} \mathrm{L}^{-1}$ in the pre and post-monsoon period total hardness value between 125 and $510 \mathrm{mgL}^{-1}$ and an average of $325.79 \mathrm{mg} \mathrm{L}^{-1}$. About 3 villages namely Kilumattur, Peraiyur and Vellore are in the desirable range and 16 wells $(84.21 \%)$ are above the desirable during the pre-monsoon period. During post-monsoon, 4 wells are within the desired range and the remaining 16 wells $(84.21 \%)$ which are widely found in the district exceed the desirable limit.

Water quality index: Water quality indexes were categorized as excellent, good, poor, very poor and unfit for drinking. WQI values in the district indicate that $1382 \mathrm{sq.} \mathrm{km}$ of the study area falls under the poor quality of drinking water during pre-monsoon season mainly distributed in the entire district except in the northwestern part. But in the postmonsoon season, 1211 sq. $\mathrm{km}$ is under poor quality mostly spread in the central part of Perambalur (Table 3). Poor and very poor water is dominantly present in the study period over the study area (Mohamed Ibraheem et al 2014). Only 376 and 547 sq.km are under good water for drinking purposes (Fig. 3h).

\section{CONCLUSION}

Domestic groundwater quality index was identified using Bureau of Indian Standards (IBS) considering ten chemical parameters such as TDS, $\mathrm{Ca}^{2+}, \mathrm{Mg}^{2+}, \mathrm{Na}^{+}, \mathrm{K}^{+}, \mathrm{Cl}, \mathrm{SO}_{4}^{2}, \mathrm{~F}, \mathrm{pH}$ and total hardness. The major factor for governing the groundwater chemistry in the Perambalur district is due to silicate weathering. The dominant cations namely $\mathrm{Na}^{+}$and $\mathrm{K}^{+}$ are present in this area. The chemical ions are presented in the order of $\mathrm{Na}^{+}-\mathrm{K}^{+}-\mathrm{Cl}-\mathrm{SO}_{4}^{2}>\mathrm{Na}^{+}-\mathrm{K}^{+}-\mathrm{HCO}_{3}>\mathrm{Ca}^{2+}-\mathrm{Mg}^{2+}-\mathrm{HCO}^{3}>$ $\mathrm{Ca}^{2+}-\mathrm{Mg}^{2+}-\mathrm{Cl}-\mathrm{SO}_{4}^{2}$ indicates alkali exceeds alkaline earth and weak acids exceed strong acids in both pre-monsoon and post-monsoon seasons. The majority of groundwater samples 
contain chemical parameters such as total hardness, TDS, $\mathrm{SO}_{4}^{2}$ and $\mathrm{Mg}^{2+}$ are exceed the permissible limit as prescribed by BIS. WQI portrays that majority of index values fall under drinking waterquality character poorly. It is necessary to advise the people about water purification while taking groundwater for drinking purposes in the Perambalur district.

\section{REFERENCES}

Adimalla Narsimha, Peiyue Li and SudarshanVenkatayogi 2018. Hydrogeochemical evaluation of groundwater quality for drinking and irrigation purposes and integrated interpretation with water quality index studies. Environmental Processes 5(2): 363-383.

Arya S, Subramani T, Vennila G and Karunanidhi D 2021. Health risks associated with fluoride intake from rural drinking water supply and inverse mass balance modeling to decipher hydrogeochemical processes in Vattamalaikarai River basin, South India. Environmental Geochemistry and Health 43(2): 705-716.

Amalraj A and Pius A 2018. Assessment of groundwater quality for drinking and agricultural purposes of a few selected areas in Tamil Nadu South India: A GIS-based study. Sustainable Water Resources Management 4(1): 1-21.

Bureau of Indian Standards (BIS) 2012. Indian Standards drinking water specifications (second revision) BIS, New Delhi, p 15.

Chaurasia AK, Pandey HK, Tiwari SK, Prakash R, Pandey $P$ and Ram A 2018. Groundwater quality assessment using water quality index (WQI) in parts of Varanasi district, Uttar Pradesh, India. Journal of the Geological Society of India 92(1): 76-82.

Divahar R, Raj PS, Sangeetha SP and Mohanakavitha T 2020. Impact Assessment of water quality for groundwater parameters on kalingarayan canal, Erode District, Tamil Nadu. Indian Journal of Ecology 47(4): 889-896.

Elumalai V, Brindha K, Bongani Sithole and E Lakshmanan 2017. Spatial interpolation methods and geostatistics for mapping groundwater contamination in a coastal area. Environmental Science and Pollution Research 24: 11601-11617.

Gorgij AD, Kisi O, Moghaddam AA and Taghipour A 2017. Groundwater quality ranking for drinking purposes, using the entropy method and the spatial autocorrelation index. Environmental Earth Sciences 76(7): 269.

Ibraheem AM, Khan SMN and Ravikumar A 2014. Seasonal variation of groundwater quality in Veppanthattai block of Perambalur district, Tamil Nadu-implements of the water quality index method. Journal of Chemical and Pharmaceutical Research 7(5): 938-943.
Jasmin I and Mallikarjuna P 2014. Physicochemical quality evaluation of groundwater and development of drinking water quality index for Araniar River Basin, Tamil Nadu, India. Environmental Monitoring and Assessment 186(2): 935-948.

Lakshmanan E, Kannan R and Kumar MS 2003. Major ion chemistry and identification of hydrogeochemical processes of ground water in a part of Kancheepuram district, Tamil Nadu, India. Environmental Geosciences 10(4): 157-166.

Narsimha Adimalla 2019. Groundwater quality for drinking and irrigation purposes and potential health risks assessment: a case study from semi-arid region of South India. Exposure and Health 11(2): 109-123.

Ramprasad C, Sona K, Afridhi M and Kumar R 2021. Water quality assessment of the Cauvery and Vaigai river at upstream and downstream locations: Impact of domestic and industrial effluents. Indian Journal of Ecology 48(2): 615-619.

Salehi S, Chizari M, Sadighi H and Bijani M 2018. Assessment of agricultural groundwater users in Iran: A cultural environmental bias. Hydrogeology Journal 26(1): 285-295.

Selvam S, Manimaran G and Sivasubramanian P 2013. Hydrochemical characteristics and GIS-based assessment of groundwater quality in the coastal aquifers of Tuticorin corporation, Tamilnadu, India. Applied Water Science 3(1): 145159.

Rao NS, Rao PS, Reddy GV, Nagamani M, Vidyasagar G and Satyanarayana NLVV 2012. Chemical characteristics of groundwater and assessment of groundwater quality in Varaha River Basin, Visakhapatnam District, Andhra Pradesh, India. Environmental Monitoring and Assessment 184(8): 5189-5214.

Vinothkanna S 2019. A Statistical Approach for Determining Ground water quality in Dindigul district, Tamil Nadu. International Journal of Research in Social Sciences 9(7): 546-554.

Vinothkanna S, Emayavaramban V, Kannadasan K and Senthilraja $K$ 2016. Assessing groundwater quality in Namakkal district, Tamil Nadu: A GIS Approach. In: D P Angadi (eds), Proceedings of the UGC sponsored $4^{\text {th }}$ International conference on Remote Sensing and GIS applications on coastal management, Feburary 16-17, 2016, Mangalore University, Mangalore. pp. 87-98.

Vinothkanna S, Rajee R and Senthilraja K 2020. Assessing ground water quality for the suitability of irrigation in Dindigul District, Tamil Nadu, India. Indian Journal of Ecology 47(1): 23-29.

Vinothkanna S, Rajee R and Senthilraja K 2020. Assessing the domestic groundwater quality of Dharmapuri District, Tamil Nadu. Research Journey International E- Research Journal 238-245.

WHO (World Health Organization) 2011. Guidelines for drinkingwater quality. World Health Organization $4^{\text {th }}$ edn., WHO Chronicle 38(4): 104-108.

Received 15 October, 2021; Accepted 28 December, 2021 